\title{
Endocrine, energy, and lipid status during parturition and early lactation in indigenous goats native to the Algerian Sahara
}

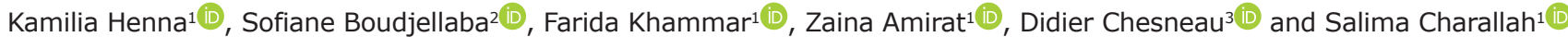

1. Department of Biology and Physiology of Organisms, University of Science and Technology Houari Boumediene, Faculty of Biological Sciences, Laboratory of Research on Arid Lands, BP 32 El Alia, 16111, Algiers, Algeria;

2. Department of Pre-Clinic, Higher National Veterinary School, Laboratory of Research Management of Local Animal Resources, Abbes Street, Oued-Smar, 16000, Algiers, Algeria; 3. Department of Animal Physiology and Farming System, University of François Rabelais, F-37041, Tours, Reproductive and Behavioral Physiology, National Institute of Agriculture, Food and Environment, INRAE UMR85, ER 11, Neuroendocrinology of sexual interactions and behaviors, CNRS, IFCE, Nouzilly, France.

Corresponding author: Kamilia Henna, e-mail: hennakamilia@gmail.com

Co-authors: SB: s.boudjellaba@ensv.dz,FK: faridakhammar@gmail.com,ZA: amiratzaina@yahoo.fr, DC: didier.chesneau@inrae.fr, SC: charalla@yahoo.fr

Received: 07-05-2021, Accepted: 11-08-2021, Published online: 18-09-2021

doi: www.doi.org/10.14202/vetworld.2021.2419-2426 How to cite this article: Henna K, Boudjellaba S, Khammar F, Amirat Z, Chesneau D, Charallah S (2021) Endocrine, energy, and lipid status during parturition and early lactation in indigenous goats native to the Algerian Sahara, Veterinary World, 14(9): 2419-2426.

\begin{abstract}
Background and Aim: Goats are widely distributed in southwest Algeria. The Saharan goat is perfectly adapted to the harsh conditions of arid areas, and it is characterized by resistance to long photoperiod and reduced metabolic needs, allowing the survival of its offspring by maintaining lactation. Several studies have demonstrated that parturition and lactation are critical periods that induce hormone, energy, and lipid status changes in mammals. However, the relationship between the blood biochemical parameters of parturition control and lactation functions in the Algerian Saharan goat has not been thoroughly documented. Therefore, this study assesses hormone and metabolite levels during parturition and early lactation in Saharan goats reared in arid areas.
\end{abstract}

Materials and Methods: Experiments were performed on 14 multiparous female goats, and blood samples were collected during parturition, 4 days postpartum (D1PP-D4PP), and during the first 12 weeks of lactation (W1-W12) to analyze prolactin, cortisol, glucose (GLU), total proteins (TP), cholesterol (CHO), triglycerides (TGs), total lipids (TL), low-density lipoproteins (LDLs), high-density lipoproteins (HDLs), and very LDLs (VLDLs).

Results: Statistical data analysis revealed a significant $(\mathrm{p}<0.05)$ increase in plasma prolactin concentrations at W1 after parturition, reaching maximum values at W3 and W9, and remained high until W12 of lactation. Plasma cortisol levels were high at parturition, reaching two peaks at W3 and W9, and then decreased at W5, W7, and W12 of lactation. No significant changes were found in serum GLU levels during the first 7 weeks of lactation compared with parturition day; then, the levels became significantly $(\mathrm{p}<0.05)$ lower at W8, W11, and W12 of lactation. Plasma TP increased significantly $(\mathrm{p}<0.05)$ at D3PP, W1, and W4, then decreased significantly $(\mathrm{p}<0.05)$ at W8. In addition, this decrease coincided with that of GLU production. Serum CHO, TGs, TL, LDLs, and VLDLs, were low at parturition and high at D4PP and during the first 3 months of lactation. Furthermore, HDL levels were low at D3PP, $1^{\text {st }}$, and $3^{\text {rd }}$ months and high at the $2^{\text {nd }}$ month of lactation.

Conclusion: This study emphasized the impact of parturition and the $1^{\text {st }}$ weeks of lactation on endocrine and metabolic changes in indigenous goats living in the Algerian Sahara Desert. These results can be used to monitor and improve farming management and understand physiological adaptive strategies, mainly lactation function sustainability, of this goat living in marginal zones.

Keywords: hormones, lactating goat, metabolic profile, parturition, Sahara.

\section{Introduction}

Indigenous goats play a crucial role in arid agricultural zones where the Saharan populations depend on them for livelihood. Several ecophysiological and metabolic studies have demonstrated their adaptive physiological characteristics to arid areas. Indeed, in these animals, the reduction of water turnover and

Copyright: Henna, et al. Open Access. This article is distributed under the terms of the Creative Commons Attribution 4.0 International License (http://creativecommons.org/licenses/by/4.0/), which permits unrestricted use, distribution, and reproduction in any medium, provided you give appropriate credit to the original author(s) and the source, provide a link to the Creative Commons license, and indicate if changes were made. The Creative Commons Public Domain Dedication waiver (http://creativecommons.org/ publicdomain/zero/1.0/) applies to the data made available in this article, unless otherwise stated. glomerular filtration rates is observed [1], and high levels of placental pregnancy-associated glycoproteins are produced, which maintain gestation [2].

Our laboratory has conducted several studies on this local breed, focusing on its reproductive endocrine ecophysiology and pathophysiology [2-6] and endocrine and metabolic response in the Saharan environment $[7,8]$. Recently, the performance of lactating goats based on relationships between milk yield and udder morphological traits was investigated [9]. The low milk production has been demonstrated, since the average daily milk yield was $0.56 \mathrm{~kg}$, reaching its peak $(0.71 \mathrm{~kg} /$ day $)$ at week 6 of lactation. This is related to the mammary gland conformation adapted for grazing in desert ranges but not suitable for high 
production; however, it does not prevent lactation sustainability and growth of kids. Therefore, assessing the endocrine and metabolic status during lactation is essential to better understand how this breed maintains lactation in an arid environment. Moreover, the mammary gland is a target of several hormones, such as prolactin and cortisol, which act synergistically to upgrade its development and function. Prolactin involved in mammary gland development controls the secretion and sustainability of milk by activating the gene transcription of caseins and enzymes and endoplasmic reticulum development. In addition, it increases neurogenesis and insulin resistance [10], while cortisol is essential for secretory activation, ample milk synthesis [11], maintaining homeostasis, and animal adaptation [12]. Furthermore, blood metabolic profile (BMP) is used to predict the emergence of some metabolic disorders, energy metabolism, and nutritional and health status in animals [13]. The indicators of BMP are mainly the hematochemical parameters, which are influenced by various factors, such as breed, age [14], gender [15], season [16], reproductive status [17], and infectious processes [18]. The most important biomarkers of energy metabolism are glucose (GLU), cholesterol (CHO), and triglycerides (TGs). The relationship between BMP and lactation function control has been previously reported in several healthy goats of various breeds $[17,19,20]$. However, there is a lack of information concerning the data of hematochemical parameters during parturition and lactation period in the Saharan breed.

This study aimed to describe the physiological changes in hormone and metabolite parameter concentrations during these reproductive phases in goats native to the Algerian Sahara Desert.

\section{Materials and Methods}

\section{Ethical approval}

The animal experiment was approved by the Ethical Committee of the Algerian Higher Education and Scientific Research (Executive Decrees No. 04-82 and No. 10-90) and agreed by the Algerian Association of Sciences in Animal Experimentation (AASEA, agreement number 45/DGLPAG/DVA.SDA.14) of the University of Science and Technology Houari Boumediene, of Algiers.

\section{Study period and location}

The study was conducted from October 2014 to September 2018 in Southwest Algeria.

\section{Animals and management}

Fourteen healthy multiparous goats (Capra hircus), 2-8 years old, weighing $19.6 \pm 4.03 \mathrm{~kg}$, were used. Animals were kept in the sheepfold of the Béni-Abbès experimental station located in the Algerian Sahara Desert $\left(30^{\circ} 07^{\prime} \mathrm{N} ., 2^{\circ} 10^{\prime} \mathrm{W}\right.$.; elevation $\left.497 \mathrm{~m}\right)$. The climate of this region is classified among the hottest and driest in Algeria, where ambient temperature can reach $47^{\circ} \mathrm{C}$ in the summer. The annual rainfall recorded is
$18 \mathrm{~mm}$ in autumn and winter. During the breeding season (autumn), the females were naturally mated with a fertile buck; in the spring, all pregnant goats gave birth to 16 kids, including seven males and nine females. Twelve dams give birth to single kids and two gave birth to twins; among them, 13 dams did not present reproductive disorders, such as dystocia, retained placenta, and uterine infections. However, the $14^{\text {th }}$ dam gave one kid from twin delivery, which died at birth due to dystocia. The dams were also healthy from any mammary gland infections (mastitis and udder edema) and incidences of metabolic disorders, such as milk fever, displacement of the abomasum, fatty liver syndrome, and ketosis. The kids permanently stayed with their mothers and were weaned at the age of 3 months. The dams were fed twice daily with a ration of $0.6 \mathrm{~kg} /$ goat of forage cereals and $0.6 \mathrm{~kg} /$ goat of barley supplemented with dates and Aristida pungens (known in Arabic as "drinn") throughout the experimental period and green alfalfa during the first postpartum (PP) days. Water and stones to lick were available ad libitum.

\section{Blood sampling}

Blood samples were collected from the external jugular vein at 08:00 a.m. before feeding. All animals were sampled at parturition (D0), PP days (D1PP-D4PP), and weekly for 12 weeks of lactation (W1-W12). The blood samples were stored in two vacutainer tubes; one contained lithium heparin for hormones and total protein (TP) assays, and the other had no anticoagulant for serum metabolites analysis. The samples were centrifuged at $3000 \times \mathrm{g}$ for $15 \mathrm{~min}$ at $4^{\circ} \mathrm{C}$. The decanted sera and plasma were stored in Eppendorf microtubes at $-20^{\circ} \mathrm{C}$ until analysis.

\section{Hormone assays}

Prolactin radioimmunoassay (PRL-RIA)

Plasma PRL was assayed in duplicate using a heterologous double-antibody RIA according to Kann [21] and Orgeur et al. [22]. The antibody anti-PRL obtained in rabbits was provided by the INRA-PRC laboratory (Nouzilly, France), and the anti-rabbit antibody (SMAL) was obtained in the ovine. The radioactivity fraction of the precipitate was quantified using a gamma counter (Packard, PerkinElmer, USA). Intra- and inter-assay coefficients of variation were $8 \%$ and $13 \%$, respectively. Assay sensitivity was $2.5 \mathrm{ng} / \mathrm{mL}$.

\section{Cortisol radioimmunoassay (CORT-RIA)}

Plasma cortisol was analyzed in duplicate, according to Murphy [23]. Cortisol antisera were produced in rabbits (Sigma-Aldrich, C8409, USA). The tritium-labeled cortisol $\left(\left[1,2,6,7-{ }^{3} \mathrm{H} \quad(\mathrm{N})\right]\right.$, PerkinElmer, NET396) was obtained from CEBCCNRS, France. The radioactivity of the precipitate was quantified using a Beta counter (Tri-Carb 2810 TR, Liquid Scintillation Analyzer, PerkinElmer). Intra- and inter-assay coefficients of variation were $14.4 \%$ and $16.4 \%$, respectively. The sensitivity of the assay was $0.16 \mathrm{ng} / \mathrm{mL}$. 
Biochemical assays

The serum metabolites were analyzed using an automated clinical chemistry analyzer (Bio lis 24i Premium Tokyo Boeki Medisys Inc. Japan) and a spectrophotometer. Bioassay kits (Biomaghreb, Tunisia) were used to assess GLU, CHO, and TGs, while Spinreact kits (S.A/S.A.U. Ctra. Santa Coloma, Spain) were used for high-density lipoprotein (HDL) analysis. Plasma TPs were measured using an auto-analyzer (Pentra C200. Horiba, France) and a commercial kit (ABX Pentra TP CP, France). Enzymatic colorimetric methods were used to assess serum GLU (GLU-oxidase/peroxidase), serum $\mathrm{CHO}$ and HDL (CHO oxidase/peroxidase), serum TG (glycerol 3-P-oxidase/peroxidase), and plasma TP (Biuret method). All coefficients of variation for intra- and inter-assay were $<10 \%$, ranging from 0.22 to $8.88 \%$ and 1.70 to $6.34 \%$, respectively. Low-density lipoproteins (LDL) and very LDL (VLDL) levels were calculated according to Friedewald et al. [24]. Total lipid (TL) levels were estimated using the formula $\mathrm{TL}=(\mathrm{CHO} \times 2.56)+(\mathrm{TG} \times 0.87)$.

\section{Statistical analysis}

The data from different variables were expressed as means \pm standard error of the mean (SEM) using SPSS for Windows v.20.0 (IBM Corp., NY, USA). The differences between various ages were estimated using Student's t-test for paired samples and normally distributed data. Wilcoxon test was used for the data with normality lower than $\mathrm{p}<0.05$. $\mathrm{p}<0.05$ was considered statistically significant.

\section{Results}

\section{Plasma prolactin and cortisol concentrations}

Our data showed non-significant $(\mathrm{p}>0.05)$ differences in plasma PRL and CORT concentrations from parturition (D0) to 4 days PP (Table-1) [25-30]. Plasma PRL levels ranged from 90.92 to $258.15 \mathrm{ng} / \mathrm{mL}$ and increased significantly $(\mathrm{p}<0.05)$ to reach a high level at W3 compared with parturition day $(258.15 \pm 36.35 \mathrm{ng} / \mathrm{mL} v s$. 96.49 $\pm 28.21 \mathrm{ng} / \mathrm{mL}$, respectively). The PRL concentrations remained high throughout the 12 weeks of lactation with a significant $(\mathrm{p}<0.01)$ increase at W9 and W10 of lactation (Figure-1a). CORT levels ranged from 9 to $26.76 \mathrm{ng} / \mathrm{mL}$; however, no significant differences were observed during the experimental period. At parturition, the mean value was $17.40 \pm 6.12 \mathrm{ng} / \mathrm{mL}$, and it decreased non-significantly at $\mathrm{W} 2$ then increased till a peak was recorded at $\mathrm{W} 3$ and $\mathrm{W} 9(26.76 \pm 5.98 \mathrm{ng} / \mathrm{mL}$ and $22.34 \pm 5.29 \mathrm{ng} / \mathrm{mL}$, respectively), followed by a decline until W12 of lactation $(9.50 \pm 2.22 \mathrm{ng} / \mathrm{mL})$ (Figure-1b).

\section{Concentration of biochemical parameters}

The obtained results revealed that serum GLU levels ranged from 2.73 to $3.54 \mathrm{mmol} / \mathrm{L}$ and gradually increased ( $p>0.05)$ with slight fluctuations from parturition to D4PP (Table-1). The highest glycemic levels were recorded on $\mathrm{W} 1$ of lactation, which declined until W7; this decrease became significant $(\mathrm{p}<0.05)$ at $\mathrm{W} 8, \mathrm{~W} 11$, and W12 of lactation (Figure-1c).

Plasma TP ranged from 33.33 to $65.64 \mathrm{~g} / \mathrm{L}$ and increased progressively from D0 to D1PP, peaking $(\mathrm{p}<0.05)$ at D3PP with a mean value of $65.64 \pm 1.86 \mathrm{~g} / \mathrm{L}$ (Table-1). The plasma TP concentration increased significantly $(\mathrm{p}<0.05)$ at W1 and W4 of lactation, which gradually decreased until W8 compared with parturition $(33.33 \pm 0.51 \mathrm{~g} / \mathrm{L} v s .51 .54 \pm 3.44 \mathrm{~g} / \mathrm{L} ; \mathrm{p}<0.05$, respectively). A gradual increase followed this decrease until W12 of lactation (Figure-1d).

Serum $\mathrm{CHO}$ ranged from 1.28 to $1.64 \mathrm{mmol} / \mathrm{L}$; significant $(\mathrm{p}<0.05)$ high concentrations of $\mathrm{CHO}$ were obtained at D4PP (Table-1), $1^{\text {st }}$, and $2^{\text {nd }}$ months of lactation compared with parturition (Table-2). Serum TG ranged from 0.11 to $0.20 \mathrm{mmol} / \mathrm{L}$ and increased ( $>0.05$ ) gradually from D0 to D2PP (Table-1); this increase became significant, reaching a maximum level at D3PP and D4PP $(0.16 \pm 0.03 \mathrm{mmol} / \mathrm{L}$ and $0.20 \pm 0.03 \mathrm{mmol} / \mathrm{L}$, respectively; $\mathrm{p}<0.05)$ compared with the time of parturition $(0.11 \pm 0.02 \mathrm{mmol} / \mathrm{L})$. TG

Table-1: Hematochemical parameters during parturition and postpartum days in indigenous goats reared in Algerian Sahara (mean $\pm S E M, n=14$ ).

\begin{tabular}{|c|c|c|c|c|c|c|}
\hline \multirow[t]{2}{*}{ Parameters } & \multirow{2}{*}{$\begin{array}{c}\text { Parturition } \\
\text { DO }\end{array}$} & \multicolumn{4}{|c|}{ Days postpartum } & \multirow{2}{*}{$\begin{array}{c}\text { Reference } \\
\text { values }\end{array}$} \\
\hline & & D1PP & D2PP & D3PP & D4PP & \\
\hline PRL (ng/mL) & $94,63 \pm 24.94^{a}$ & $138,17 \pm 51.83^{a}$ & $90,92 \pm 20.73^{a}$ & $130,73 \pm 41.58^{a}$ & $130,79 \pm 41 \cdot 17^{a}$ & $0-100[25]$ \\
\hline CORT $(\mathrm{ng} / \mathrm{mL})$ & $17,40 \pm 6.12^{a}$ & $9,44 \pm 1.69^{a}$ & $13,34 \pm 4.06^{a}$ & $15,55 \pm 3.52^{\mathrm{a}}$ & $11,36 \pm 2.23^{a}$ & $1-34[26]$ \\
\hline GLU (mmol/L) & $3,14 \pm 0.11^{\mathrm{a}}$ & $3,15 \pm 0.07^{a}$ & $3,26 \pm 0.11^{a}$ & $3,05 \pm 0.12^{\mathrm{a}}$ & $3,30 \pm 0.10^{a}$ & $2.8-4.2$ [27] \\
\hline $\mathrm{CHO}(\mathrm{mmol} / \mathrm{L})$ & $1,28 \pm 0.06^{\mathrm{a}, \mathrm{d}}$ & $1,34 \pm 0.08^{a, c}$ & $1,46 \pm 0.06^{b, c, e}$ & $1,53 \pm 0.13^{d, e, g}$ & $1,64 \pm 0.05^{f, g}$ & $1.07 \pm 0.13[28]$ \\
\hline TG (mmol/L) & $0,11 \pm 0.02^{\mathrm{a}, \mathrm{d}}$ & $0,12 \pm 0.01^{a, c, d}$ & $0,13 \pm 0.02^{\mathrm{a}, \mathrm{e}}$ & $0,16 \pm 0.03^{\mathrm{d}, \mathrm{f}}$ & $0,20 \pm 0.03^{b, c, e, f}$ & $0.16-1.6$ [29] \\
\hline $\mathrm{TP}(\mathrm{g} / \mathrm{L})$ & $51,54 \pm 3.44^{a, c}$ & $59,84 \pm 1.54^{a}$ & $42,10 \pm 4.44^{c, d}$ & $65,64 \pm 1.86^{b}$ & $55,36 \pm 3.80^{a, d}$ & 63-85 [29] \\
\hline TL (g/L) & $1,32 \pm 0.06^{\mathrm{a}, \mathrm{d}}$ & $1,42 \pm 0.08^{a, c}$ & $1,54 \pm 0.07^{b, c}$ & $1,64 \pm 0.15^{\mathrm{d}, \mathrm{f}}$ & $1,77 \pm 0.05^{\mathrm{e}, \mathrm{f}}$ & NA \\
\hline LDL (mmol/L) & $0,13 \pm 0.04^{a, d}$ & $0,24 \pm 0.05^{a, c}$ & $0,33 \pm 0.06^{b, c, e}$ & $0,44 \pm 0.11^{\mathrm{d}, \mathrm{e}, \mathrm{g}}$ & $0,49 \pm 0.05^{f, g}$ & $0.72 \pm 0.05[30]$ \\
\hline HDL (mmol/L) & $1,11 \pm 0.06^{a}$ & $1,04 \pm 0.04^{a}$ & $1,07 \pm 0.03^{a}$ & $1,02 \pm 0.04^{a}$ & $1,06 \pm 0.04^{a}$ & $1.68 \pm 0.11[30]$ \\
\hline VLDL (mmol/L) & $0,05 \pm 0.01^{a, b}$ & $0,05 \pm 0.01^{a, b}$ & $0,06 \pm 0.01^{a}$ & $0,07 \pm 0.02 b,{ }^{c}$ & $0,09 \pm 0.01^{a, c}$ & NA \\
\hline
\end{tabular}

Wilcoxon test was applied for all hematochemical parameters. Means in the same line with different superscript letters are significantly different $(p<0.05)$. Values with the same letter did not differ significantly. $D 0=P a r t u r i t i o n$, $\mathrm{D} 1-\mathrm{D} 4=$ Postpartum days, $\mathrm{NA}=$ Not available. PRL=Prolactin, $\mathrm{CORT}=$ Cortisol, $\mathrm{GLU}=\mathrm{Glucose}, \mathrm{CHO}=\mathrm{Cholesterol}$,

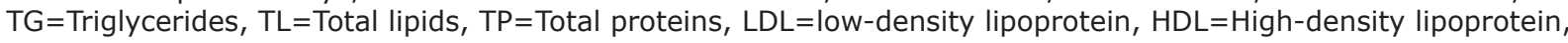
$\mathrm{VLDL}=$ Very low-density lipoprotein 
levels increased non-significantly during the 3 months of lactation (Table-2). Serum TL ranged from 1.32 to $1.80 \mathrm{~g} / \mathrm{L}$ and significantly increased $(\mathrm{p}<0.05)$ progressively from D0 to D4PP recorded at D3PP and D4PP (Table-1); this rise remained until the $3^{\text {rd }}$ month of lactation compared with the day of parturition (Table-2).

Concerning the lipoprotein levels, serum LDL ranged from 0.13 to $0.49 \mathrm{mmol} / \mathrm{L}$, increased significantly $(\mathrm{p}<0.05)$ from D2PP to D4PP (Table-1), and remained high until the $3^{\text {rd }}$ month of lactation $(0.45 \pm 0.04 \mathrm{mmol} / \mathrm{L})$ compared with the day of parturition $(0.13 \pm 0.04 \mathrm{mmol} / \mathrm{L})$ (Table-2). Serum HDL ranged from 0.99 to $1.19 \mathrm{mmol} / \mathrm{L}$ and decreased progressively ( $>0.05$ ) from D0 to D4PP (Table-1), then decreased gradually to reach a lower rate at the $3^{\text {rd }}$ month of lactation (Table-2). Finally, serum VLDL ranged from 0.05 to $0.09 \mathrm{mmol} / \mathrm{L}$ and increased progressively $(\mathrm{p}>0.05)$ from parturition to D4PP (Table-1), then fluctuated until the $3^{\text {rd }}$ month of lactation (Table-2).

\section{Discussion}

This study provides significant variations in the endocrine and metabolic patterns during parturition and lactation in the indigenous goat, which is perfectly adapted to the adverse conditions of arid areas of Algeria. The hematochemical parameters investigated in this breed were in the physiological range (Table-1). PRL plays a fundamental role in the lactation of farm animals; it is the lactogenic hormone in mammals, which plays an important role in milk production control in dairy ruminants.

This study reported that plasma PRL increased with increased lactation with a peak at W3 and W9 of lactation. Similar results were reported in Turkish Saanen goat [31], whereas Castro et al. [32] reported that prolactinemia peaked at parturition and significantly dropped on the $1^{\text {st }}$ day of PP, followed by a sharp increase on the $4^{\text {th }}$ day after parturition. Moreover, in Israeli dairy Saanen goat, PRL level was higher at
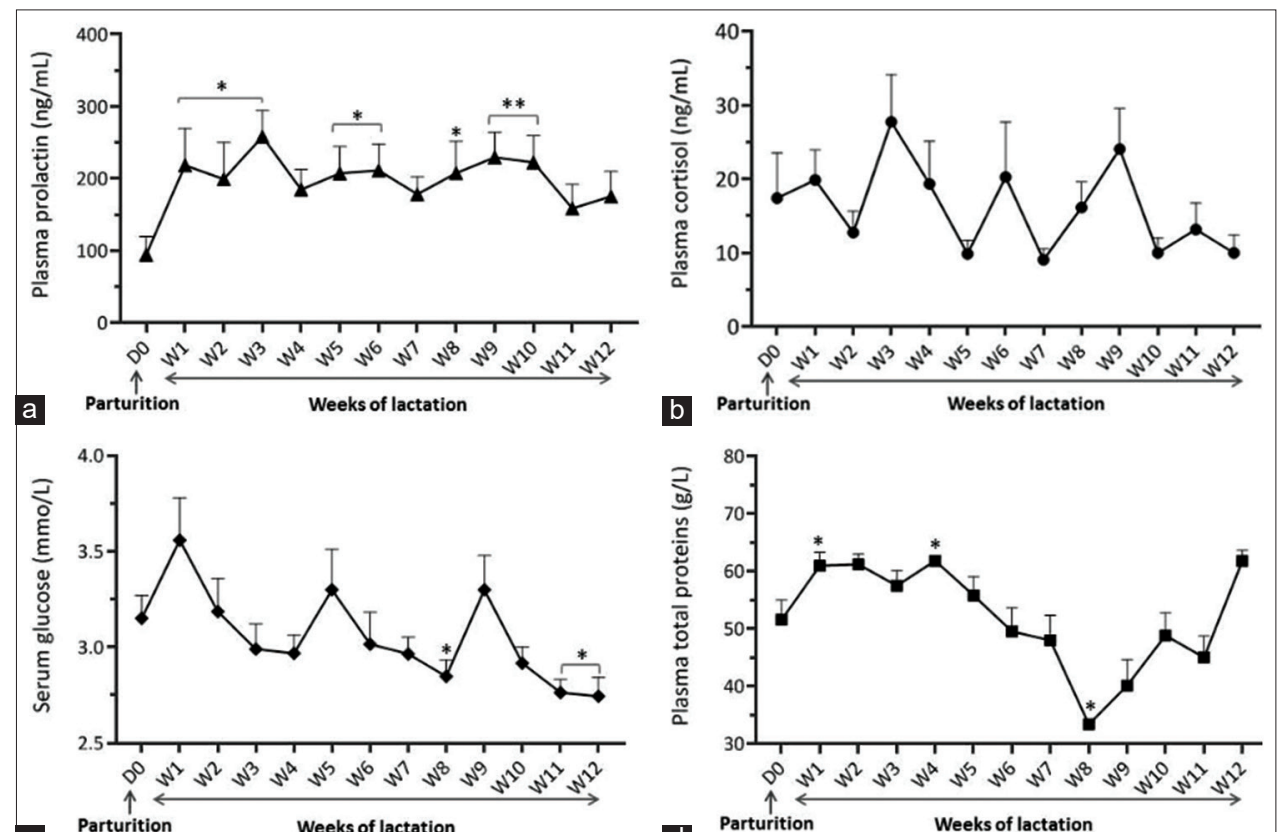

C

Parturition

Weeks of lactation

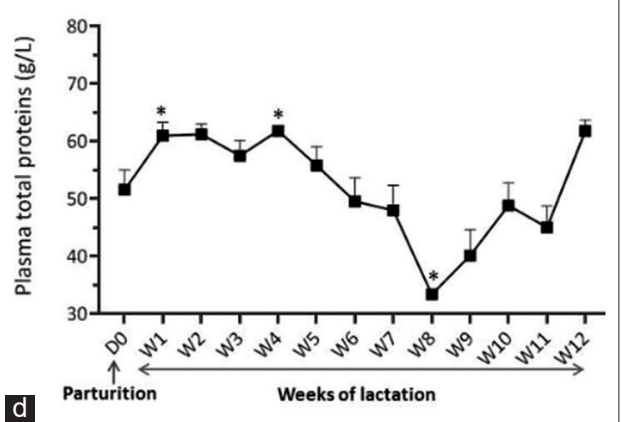

Figure-1: Circulating profiles of prolactin (a), cortisol (b), glucose, (c) and total proteins (d) at parturition (D0) and early lactation (W1 to W12) in indigenous goats reared in Algerian Sahara. (Mean \pm SEM, $n=14$ ). * indicate $p<0.05, * *$ indicate $\mathrm{p}<0.01$.

Table-2: Serum lipids during parturition and early lactation stages in indigenous goats reared in Algerian Sahara (mean \pm SEM, $n=14)$.

\begin{tabular}{|c|c|c|c|c|}
\hline \multirow[t]{2}{*}{ Parameters } & \multirow{2}{*}{$\begin{array}{c}\text { Parturition } \\
\text { DO }\end{array}$} & \multicolumn{3}{|c|}{ First months of lactation } \\
\hline & & W1-W4 & W5-W8 & W9-W12 \\
\hline $\mathrm{CHO}(\mathrm{mmol} / \mathrm{L})$ & $1,28 \pm 0.18^{\mathrm{a}}$ & $1.55 \pm 0.04^{b, c}$ & $1.63 \pm 0.05^{\mathrm{b}}$ & $1.53 \pm 0.04^{\mathrm{a}, \mathrm{c}}$ \\
\hline $\mathrm{TG}(\mathrm{mmol} / \mathrm{L})$ & $0,11 \pm 0.02^{a}$ & $0.14 \pm 0.01^{a}$ & $0.16 \pm 0.01^{\mathrm{a}}$ & $0.15 \pm 0.01^{\mathrm{a}}$ \\
\hline $\mathrm{TL}(\mathrm{g} / \mathrm{L})$ & $1,32 \pm 0.05^{a}$ & $1.65 \pm 0.04^{\mathrm{b}, \mathrm{d}}$ & $1.80 \pm 0.05^{c}$ & $1.63 \pm 0.04^{\mathrm{a}, \mathrm{d}}$ \\
\hline LDL (mmol/L) & $0,13 \pm 0.04^{a}$ & $0.42 \pm 0.03^{b}$ & $0.42 \pm 0.03^{b}$ & $0.45 \pm 0.04^{b}$ \\
\hline HDL (mmol/L) & $1,11 \pm 0.06^{a, b}$ & $1.08 \pm 0.02^{\mathrm{a}}$ & $1.15 \pm 0.02^{\mathrm{a}}$ & $1.04 \pm 0.02^{\mathrm{b}}$ \\
\hline VLDL (mmol/L) & $0,05 \pm 0.01^{a}$ & $0.07 \pm 0.00^{a}$ & $0.07 \pm 0.00^{a}$ & $0.07 \pm 0.00^{a}$ \\
\hline
\end{tabular}

Differences among the mean concentrations of each lipid parameter in the different groups were analyzed by Test $t$ of Student. Mean in the same line with different superscript letters are significantly different $(p<0.05)$. Values with the same letter did not differ significantly. D0=parturition, $W 1-W 4=1^{\text {st }}$ month of lactation, W5-W $8=2^{\text {nd }}$ month of lactation, W9-W12 $=3^{\text {rd }}$ month of lactation. $\mathrm{CHO}=$ Cholesterol, $\mathrm{TG}=$ Triglycerides, $\mathrm{TL}=$ Total lipids, $\mathrm{LDL}=\mathrm{Low}$-density lipoprotein, $\mathrm{HDL}=$ High-density lipoprotein, VLDL=Very low-density lipoprotein 
parturition then decreased progressively from $\mathrm{W} 1$ and W9 of PP [33]. In ruminants, the increase in prolactinemia after parturition is necessary for maintaining lactation [34]. This has also been confirmed in the Saharan breed, where we recorded elevated PRL levels throughout lactation. This rise could be due to the stimulation of suckling by kids; thus, inducing PRL release [35]. In addition, kids were kept with their dams and suckled ad libitum throughout lactation; this agrees with the elevated prolactinemia noted during the lactation period. It can also be related to a rise in ambient temperature, which can reach $47^{\circ} \mathrm{C}$ during summer. Furthermore, Sano et al. [25] found a strong positive correlation between PRL secretion and the increase in ambient temperature. Hence, high temperature is an exogenous factor stimulating the secretion of PRL, allowing the sustainability of lactation in arid areas. In contrast, low PRL concentration observed at parturition may be due to the increase in oestradiol-17 $\beta$ level, which inhibits the increase in PRL receptors in the mammary cells during pregnancy [36]. Furthermore, the decline in progesterone (P4) level at parturition induces a change in the $\mathrm{P} 4 / \mathrm{PRL}$ ratio and an increase in the number of PRL receptors in the mammary gland. Furthermore, our results demonstrated two synergic high plasma PRL and CORT rates at $\mathrm{W} 3$ and $\mathrm{W} 9$ of lactation. Thus, CORT may be essential for growth and histological differentiation of the mammary gland and constitutes an enhancer of lactogenic hormone complex, particularly PRL. Plasma cortisol levels fluctuated from D0 to W12 with a high level at W3 and W9 of lactation. This result is similar to Turkish Saanen goat [31]. High cortisol levels are required to keep up intense milk synthesis and secretion during lactation; high cortisol levels recorded at parturition can be associated with labor stress, high ambient temperature, or feed restriction, which are severe stressors stimulating the hypothalamic-pituitary-adrenal (HPA) axis. According to the literature, several studies on lactating goats reared under arid and semi-arid climates reported that cortisol concentration does not exceed $9 \mathrm{ng} / \mathrm{mL}[16,37,38]$. In contrast, we reported a higher cortisol level in our breed, reaching a value of about $26.76 \mathrm{ng} / \mathrm{mL}$. This rise may be related to the ecophysiological responses to the arid environment, involving the activation of the HPA axis with an increase in corticotropin-releasing, antidiuretic, and adrenocorticotropic hormone production [8]. Consequently, the increase in CORT production promotes protein catabolism, and converting proteins into amino acids to support gluconeogenesis.

GLU is an essential energetic substrate and is an important component of lactose, which plays a primary role in milk production. The GLU levels obtained in the Saharan breed increased progressively from D0 to D4PP and peaked at W1 after parturition, then significantly dropped at W8, W11, and W12 of lactation. This decrease may be linked to high energy demands of the mammary gland for lactose milk synthesis, greater insulinemia activity, or an increase in ambient temperature, which negatively affects the hypothalamic center (appetite control), causing a low feed intake [39]. This reduction may also be associated with a negative energy balance, leading to lipolysis, which increases non-esterified fatty acid (NEFA) levels used for TG synthesis. This case supports our study results, which recorded a high triglyceridemia with low glycemia. Our results agree with those found in Brazilian dairy [40] and Croatian Alpine goats [41]. Hyperglycemia observed at W1 of lactation could be ascribed to the low responsiveness of peripheral tissues to insulin. In addition, an increase in milk production demonstrated that animals were in a positive energy balance and a high CORT level that increases hepatic gluconeogenesis; this case confirms our study where we recorded simultaneously high cortisol and GLU levels.

The low TP levels recorded at parturition in our study may be an adaptive response to the high requirement for water mobilization from blood to mammary glands for lactogenesis. Increased TP levels recorded during lactation are due to immunoglobulin transfer from the bloodstream to the mammary gland. Our study observed a significant decline in TP at W8, coinciding with that of GLU; thus, it allows the udder to increase lactose and immunoglobulin rates for milk production [42]. A remarkable decrease in TP was recorded from W5 to W9 of lactation, coinciding with a significant increase in PRL rates; this was explained by TP infiltration of the blood toward anterior pituitary lactotroph cells for synthesizing PRL, which acts directly on alveolar epithelial cells to increase the expression of genes for milk proteins and stimulates lipid and carbohydrate synthesis and the transport of ions in milk. This effect is potentiated by CORT, insulin, insulin-like growth factor, and growth hormone, which multiply the intracellular organelles essential for proteinogenesis.

$\mathrm{CHO}$ belongs to the sterol family and plays a key role in many biochemical processes. $\mathrm{CHO}$ and TG levels are used as an indicator of lipid profile. Cholesterolemia obtained was lower on D0, then peaked at D4PP and remained high until the $3^{\text {rd }}$ month of lactation. Our results agree with those of Aardi goats in Saudi Arabia [43] and red Syrian goats [44]. However, Iriadam [45] had a significant increase in parturition in Kilis goats. In the Saharan breed, hypocholesterolemia recorded at parturition can be due to adrenal and ovarian steroid production, fat-soluble vitamin production, and high thyroid hormone levels [46]. The latter inhibits the activity of $\beta$-hydroxy $\beta$-methylglutaryl CoA reductase, a crucial enzyme regulating $\mathrm{CHO}$ synthesis, whereas glucagon and glucocorticoids decrease it [40]. The hypercholesterolemia recorded during lactation suggests lipid mobilization mediated by glucagon, an acute synthesis of plasma lipoproteins, an important feed intake for milk synthesis, or the estrogens that stimulate $\mathrm{CHO}$ synthesis. This rise can also be due to a reduction in lipogenesis, 
lipid esterification, and catecholamine increase, which induces NEFA release [47].

TGs are major components of VLDL and chylomicrons and are considered an energy source and play a role in dietary fat transport. TG levels obtained increased from D0 until the $3^{\text {rd }}$ month of lactation. These data are similar to those reported by Allaoua and Mahdi [48] in Arbia goats. Hypotriglyceridemia recorded at D0, D1PP, and D2PP may be explained by milk fat production using peripheral blood of TG, hyperactivity of lipoprotein lipases, and NEFA level reduction [49]. However, hypertriglyceridemia observed during lactation may be related to hormonal regulation $(\mathrm{P} 4$, glucocorticosteroids, catecholamines, and glucagon) and NEFA level increase used for TG synthesis. Serum TL obtained in Saharan goats were low at D0 and high at D4PP until the $3^{\text {rd }}$ month of lactation. This rise can be related to the inhibition of apoprotein synthesis and their receptors, which are essential for VLDL and P4 production [50].

Concerning lipoprotein levels, serum LDL increased significantly from D4PP until the $3^{\text {rd }}$ month of lactation compared with parturition. Similar results were found in the Croatian Alpine [41] and the Maltese goats [47]; Tharwat et al. [51] reported higher LDL levels at parturition in Saudi Arabian goats. The high levels of LDL and CHO obtained in our breed reflect high cortisol levels during lactation, indicating the role of LDL in transporting $\mathrm{CHO}$ from plasma to cells of the adrenal cortex for CORT synthesis. Serum HDL showed a decrease at D3PP, $1^{\text {st }}$, and $3^{\text {rd }}$ months and increased at the $2^{\text {nd }}$ month of lactation. This is similar to that observed in other goat breeds $[47,51,52]$. Concerning serum VLDL, it increased from parturition until the $3^{\text {rd }}$ month of lactation. In addition, NEFA levels can be re-esterified in the liver mitochondria and peroxisomes to TG, which is involved in VLDL formation [53]. The high VLDL, HDL, and GLU levels obtained may be caused by the monitoring role of GLU on their excretion from the liver and blood.

\section{Conclusion}

This study showed that parturition and the first 12 weeks of lactation are critical physiological stages because most metabolic changes occur during this period. Therefore, through our results, circulating hormones and metabolic parameters will help breeders and veterinarians for the best management of reproduction to improve production in indigenous Saharan goats. Furthermore, PRL, CORT, and metabolite parameter levels can also serve for early diagnosis and prognosis of blood changes due to metabolic disorders during these physiological stages. Moreover, even though the udder of this breed had a small size, a suspensory system of medium strength, and teats of a shape not entirely favorable to milking, it revealed perfect endocrine and metabolic profiles that maintained lactation and ensured the growth of its offspring under the hostile conditions of its biotope. Thus, we can conclude that this Saharan breed presents adaptive responses expressed by metabolic and hormonal variations modulated by physiological cellular and molecular mechanisms. Hence, it is important to deepen the endocrine and energetic metabolism involvement in this breed, particularly by assessing estradiol $17 \beta$, thyroid hormones, NEFA, and $\beta$-hydroxybutyrate.

\section{Authors' Contributions}

KH: Carried out animal experimentation, biochemical assays, analyzed the results, and wrote the article. SB: Carried out the statistical analysis. FK: Coordinated the research activity planning and execution and commented on the manuscript. ZA: Interpretation of the results and English editing. DC: Performed the prolactin assays. SC: Designed the study, interpretation of the results, and drafted and revised the manuscript. All authors read and approved the final manuscript.

\section{Acknowledgments}

The authors acknowledge $\mathrm{M}$. Yaïche and $\mathrm{H}$. Salmi for their assistance in blood sampling and animal care. We thank X. Bonnet, B. Michaud and C. Trouve from CEBC, CNRS (France), for cortisol and total proteins analysis. Special thanks to A. Sempere from CEBC and P. Chemineau from INRA, Nouzilly (France), for the prolactin assay. The authors also thank A. Kouri from University of Science and Technology Houari Boumediene, Algiers, for her help in animal experimentation. This research was supported by the Algerian Ministry of Higher Education and Scientific Research, project number: F 00220120046.

\section{Competing Interests}

The authors declare that they have no competing interests.

\section{Publisher's Note}

Veterinary World remains neutral with regard to jurisdictional claims in published institutional affiliation

\section{References}

1. Silanikove, N. (1984) Renal excretion of urea in response to changes in nitrogen intake in desert (black Bedouin) and non-desert (Swiss Saanen) goats. Comp. Biochem. Physiol. A Comp. Physiol., 79(4): 651-654.

2. Charallah, S., Amirat, Z., Sulon, J., Khammar, F. and Beckers, J.F. (2010) Pregnancy-associated glycoprotein and progesterone concentrations during pregnancy failure in bedouin goat from the Southwest of Algeria. Reprod. Domest. Anim., 45(6): e231-e238.

3. Charallah, S., Lakhdari, Y., Amirat, Z., Khammar, F. and Sempere, A. (1993) Variations hormonales saisonnières de l'activité sexuelle chez les chèvres bédouines. Bul. Soc. Ecophysiol., 18(1-2): 67-70.

4. Malek, M., Amirat, Z., Khammar, F. and Khaldoun, M. (2016) Analysis of the energetic metabolism in cyclic Bedouin goats (Capra hircus): Nychthemeral and seasonal variations of some haematochemical parameters in relation with body and ambient temperatures. J. Therm. Biol., 60: 86-94. 
5. Kassouri-Maouche, S., Boukenaoui-Ferrouk, N., Charallah, S., Moudilou, E., Chakhma, A., Exbrayat, J.M. and Khammar, F. (2018) Atretic ovarian follicles morphology and immunolocalization of active caspase-3 in Algerian Bedouin goat (Capra hircus) ovaries. Kafkas Univ. Vet. Fak. Derg., 25(2): 147-156.

6. Kouri, A., Charallah, S., Kouri, F., Amirat, Z. and Khammar, F. (2018) Reproductive performances and abortion etiologies of native Bedouin goats in the arid zones of Algeria. Livest. Res. Rural Dev., 30(7): 1-7.

7. Chergui, N., Mormede, P., Foury, A., Khammar, F. and Amirat, Z. (2017) Seasonal effects on plasma cortisol concentrations in the Bedouin buck: Circadian studies and response to ACTH. Animal, 11(3): 445-451.

8. Chakhma, A., Khaldoun-Benabbas, M., CharallahCherif, S., Kassouri, S., Khammar, F. and Amirat, Z. (2021) Annual changes in plasma progesterone and estradiol-17 $\beta$ concentrations compared to pituitary-adrenal axis activity in the female goat reared under arid environment. Biol. Rhythm Res., 52(9): 1394-1411.

9. Kouri, F., Charallah, S., Kouri, A., Amirat, Z. and Khammar, F. (2019) Milk production and its relationship with milk composition, body and udder morphological traits in Bedouin goat reared under arid conditions. Acta Sci. Anim. Sci., 41(1): e42552.

10. Lopez-Vicchi, F. and Becu-Villalobos, D. (2017) Prolactin: The bright and the dark side. Endocrinology, 158(6): 1556-1559.

11. Casey, T.M. and Plaut, K. (2007) The role of glucocorticoids in secretory activation and milk secretion, a historical perspective. J. Mammary Gland Biol. Neoplasia, 12(4): 293-304.

12. Ribeiro, M.N., Ribeiro, N.L., Bozzi, R. and Costa, R.G. (2018) Physiological and biochemical blood variables of goats subjected to heat stress: A review. J. Appl. Anim. Res., 46(1): 1036-1041.

13. Antunović, Z., Novoselec, J., Sauerwein, H., Speranda, M., Vegara, M. and Pavic, V. (2011) Blood metabolic profile and some of hormones concentration in ewes during different physiological status. Bulg. J. Agric. Sci., 17(5): 687-695.

14. Antunović, Z., Novaković, K., Klir, Ž., Šerić, V., Mioč, B., Šperanda, M., Ronta, M. and Novoselec, J. (2020) Blood metabolic profile and acid-base status of Istrian goats a critically endangered Croatian goat in relation to age. Vet. Arhiv, 90(1): 27-38.

15. Habibu, B., Kawu, M., Aluwong, T. and Makun, H. (2017) Influence of seasonal changes on physiological variables, haematology and serum thyroid hormones profile in male Red Sokoto and Sahel goats. J. Appl. Anim. Res., 45(1): 508-516.

16. Ribeiro, N.L., Germano-Costa, R., Pimenta-Filho, E.C., Ribeiro, M.N. and Bozzi, R. (2018) Effects of the dry and the rainy season on endocrine and physiologic profiles of goats in the Brazilian semi-arid region. Ital. J. Anim. Sci., 17(2): 454-461.

17. Madan, J., Sindhu, S. and Rose, M.K. (2020) Changes in plasma biochemical parameters and hormones during transition period in Beetal goats carrying single and twin fetus. Vet. World, 13(6): 1025-1029.

18. Garba, B., Habibullah, S.A., Saidu, B. and Suleiman, N. (2019) Effect of mastitis on some hematological and biochemical parameters of Red Sokoto goats. Vet. World, 12(4): 572-577.

19. El-Tarabany, M.S., Abdel-Hamid, T.M., Ahmed-Farid, O.A. and Al-Marakby, K.M. (2019) Characterization of progesterone profile, physiological responses, milk composition and blood biochemical and hematological indices at the early stage of lactation in goats. Biol. Rhythm Res., 50(4): 647-657.

20. Cepeda-Palacios, R., Fuente-Gómez, M.G., RamírezOrduña,J.M., García-Álvarez, A., Llinas-Cervantes, X. and Angulo, C. (2018) Effects of pregnancy and post-kidding stages on haematochemical parameters in cross-bred goats. J. Appl. Anim. Res., 46(1): 269-273.

21. Kann, G. (1971) Dosage radio-immunologique de la prolactine plasmatique chez les ovins. C. R. Acad. Sci. Paris Ser D, 272: 2808-2811.

22. Orgeur, P., Mavric, N., Yvore, P., Bernard, S., Nowak, R., Schaal, B. and Levy, F. (1998) Artificial weaning in sheep: consequences on behavioural, hormonal and immuno-pathological indicators of welfare. Appl. Anim. Behav. Sci., 58(1-2): 87-103.

23. Murphy, B.E.P. (1967) Some studies of the protein-binding of steroids and their application to the routine micro and ultramicro measurement of various steroids in body fluids by competitive protein-binding radioassay. J. Clin. Endocrinol. Metab., 27(7): 973-990.

24. Friedewald, W.T., Levy, R.I. and Fredrickson, D.S. (1972) Estimation of the concentration of low-density lipoprotein cholesterol in plasma, without use of the preparative ultracentrifuge. Clin. Chem., 18(6): 499-502.

25. Sano, H., Ambo, K. and Tsuda, T. (1985) Blood glucose kinetics in whole body and mammary gland of lactating goats exposed to heat. J. Dairy Sci., 68(10): 2557-2564.

26. Nodari, S.R., Gaffuri, A., Cova, M., Bencetti, F., Archetti, I., Polloni, A., Santi, A. and Galletti, G. (2016) Reference intervals for serum haptoglobin, cortisol and lysozyme in immediate post-partum and lactating dairy goats. Large Anim. Rev., 22(6): 267-270.

27. Kaneko, J.J. (1997) Clinical Biochemistry of Domestic Animals. $5^{\text {th }}$ ed. Academic Press, San Diego. p45-80.

28. Opara, M., Udevi, N. and Okoli, I. (2010) Haematological parameters and blood chemistry of apparently healthy West African Dwarf (Wad) goats in Owerri, South Eastern Nigeria. N. Y. Sci. J., 3(8): 68-72.

29. Daramola, J., Adeloye, A., Fatoba, T. and Soladoye, A. (2005) Haematological and biochemical parameters of West African Dwarf goats. Livest. Res. Rural Dev., 17(8): 95.

30. Elitok, B. (2012) Reference values for hematological and biochemical parameters in Saanen goats breeding in Afyonkarahisar province. Kocatepe Vet. J., 5(1): 7-11.

31. Guzel, S. and Belenli, D. (2015) The interrelationship between resistin and amylin plasma concentrations and their relation to the concentrations of selected reproductive and metabolic hormones and biochemical variables in the early lactation stage of Saanen goats. Rev. Med. Vet. (Toulouse), 166(7): 229-233

32. Castro, N., Capote, J., Batista, M., Bruckmaier, R. and Argüello, A. (2011) Effects of induced parturition in goats on immunoglobulin $\mathrm{G}$ and chitotriosidase activity in colostrum and plasma and on plasma concentrations of prolactin. Domest. Anim. Endocrinol., 40(4): 192-196.

33. Mabjeesh, S., Gal-Garber, O. and Shamay, A. (2007) Effect of photoperiod in the third trimester of gestation on milk production and circulating hormones in dairy goats. $J$. Dairy Sci., 90(2): 699-705.

34. Akersr, M.R., Bauman, D.E., Capuco, A.V., Goodman, G.T. and Tucker, A.H. (1981) Prolactin regulation of milk secretion and biochemical differentiation of mammary epithelial cells in periparturient cows. Endocrinology, 109(1): 23-30.

35. Schirar, A., Cognié, Y., Louault, F., Poulin, N., Meusnier, C., Levasseur, M. C. and Martinet, J. (1990) Resumption of gonadotrophin release during the postpartum period in suckling and non-suckling ewes. J. Reprod. Fertil., 88(2): 593-604.

36. Khan, J. and Ludri, R. (2002) Changes in blood glucose, plasma non-esterified fatty acids and insulin in pregnant and non-pregnant goats. Trop. Anim. Health Prod., 34(1): 81-90.

37. Bhat, I.H., Devi, J., Kour, K. and Sarma, K. (2016) Blood biochemical profile and cortisol level in Toggenburg goat during lactation. J. Anim. Res., 6(5): 873-878.

38. Ribeiro, N.L., Costa, R.G., Pimenta-Filho, E.C., Ribeiro, M.N., Crovetti, A., Saraiva, E.P. and Bozzi, R. (2016) Adaptive profile of Garfagnina goat breed assessed through physiological, haematological, biochemical and 
hormonal parameters. Small Rumin. Res., 144: 236-241.

39. Baile, C.A. and Forbes, J.M. (1974) Control of feed intake and regulation of energy balance in ruminants. Physiol. Rev., 54(1): 160-214.

40. Soares, G., Souto, R., Cajueiro, J., Afonso, J., Rego, R., Macêdo, A., Soares, P. and Mendonça, C. (2018) Adaptive changes in blood biochemical profile of dairy goats during the period of transition. Rev. Med. Vet., 169(1-3): 65-75.

41. Antunović, Z., Šperanda, M., Novoselec, J., Đidara, M., Mioč, B., Klir, Ž. and Samac, D. (2017) Blood metabolic profile and acid-base balance of dairy goats and their kids during lactation. Vet. Arhiv, 87(1): 43-55.

42. Bagnicka, E., Jarczak, J., Kosciuczuk, E., Kaba, J. and Jozwik, A. (2014) Active dry yeast culture supplementation effect on the blood biochemical indicators of dairy goats. $J$. Adv. Dairy Res., 2(2): 1-7.

43. Al-Hassan, M.J. (2018) Metabolic profiles of healthy preand postpartum Aardi goats (Capra hircus) and kids in Saudi Arabia. Pak. Vet. J., 38(4): 424-428.

44. Celi, P., Di Trana, A. and Quaranta, A. (2008) Metabolic profile and oxidative status in goats during the peripartum period. Aust. J. Exp. Agric., 48(6-7): 1004.

45. Iriadam, M. (2007) Variation in certain hematological and biochemical parameters during the peri-partum period in Kilis does. Small Rumin. Res., 73(1-3): 54-57.

46. Gueorguieva, T. and Gueorguiev, I.P. (1997) Parturition and in early lactation in dairy cows. Rev. Med. Vet., 148(3):
241-244.

47. Zumbo, A., Di Rosa, A.R., Casella, S. and Piccione, G. (2007) Changes in some blood haematochemical parameters of Maltese goats during lactation. J. Anim. Vet. Adv., 6(5): 706-711.

48. Allaoua, S.A. and Mahdi, D. (2018) Plasma biochemical and minerals parameters in Arbia goats of a semi-arid region of North-Eastern Algeria during different stages of production. Vet. Arhiv, 88(5): 643-660.

49. Karapehlivan, M., Atakisi, E., Atakisi, O., Yucayurt, R. and Pancarci, S. (2007) Blood biochemical parameters during the lactation and dry period in Tuj ewes. Small Rumin. Res., 73(1-3): 267-271.

50. Grummer, R. and Carroll, D. (1988) A review of lipoprotein cholesterol metabolism: Importance to ovarian function. $J$. Anim. Sci., 66(12): 3160-3173.

51. Tharwat, M., Ali, A. and Al-Sobayil, F. (2013) Hematological and biochemical profiles in goats during the transition period. Comp. Clin. Pathol., 24(1): 1-7.

52. Skotnicka, E., Muszczyński, Z. and Suska, M. (2011) Effect of the periparturient period on serum lipid and cholesterol lipoprotein concentrations in goats (Capra hircus). Acta. Vet. Hung., 59(4): 445-454.

53. Constable, P.D., Hinchcliff, K.W., Done, S.H. and Gruenberg, W. (2017) Veterinary Medicine: A Textbook of the Diseases of Cattle, Horses, Sheep, Pigs and Goats. $11^{\text {th }}$ ed. Elsevier Ltd., Amsterdam, Netherlands. p1662-1756. 